Miralles-Marcelo, Miralles-Quirós and Lisboa (2015) / Revista de Empresa Familiar, 5(1), 17-25.

www.revistadeempresafamiliar.uma.es

\title{
Does family control reduce firm risk?
}

\author{
Jose Luis Miralles-Marcelo $^{\mathrm{a}^{*}} \cdot$ María del Mar Miralles-Quirós $^{\mathrm{a}} \cdot$ Ines Lisboa $^{\mathrm{b}}$ \\ ${ }^{a}$ Facultad de Ciencias Económicas y Empresariales. Universidad de Extremadura (Spain). \\ ${ }^{b}$ School of Technology and Management, Management for Sustainability Research Centre, Polytechnic Institute of \\ Leiria (Portugal).
}

A R T I C L E IN F O

Article history:

Received 19-02-2014

Accepted 13-02-2015

Keywords:

Family Firm

Family control

F-PEC scale

Firm Risk

JEL codes:

G10, G14, M10, M20

\section{A B S T R A C T}

In the current context of instability and financial crisis, understanding firm risk is crucial. In this study we aim to assess firm risk differences between family and non-family firms. Furthermore we analyze the family control impact, measured by both the family ownership and the F-PEC scale, in firm risk. We provide new evidence from family firm studies since we not only analyze the risk topic, almost unexplored, but we also introduce the F-PEC scale, an alternative way to measure the family influence. Using Portuguese quoted firms during the 19992012 period, we find that family influence and control do not impact firm risk. Moreover, the firm size, return and growth opportunities influence it.

\footnotetext{
* Corresponding author.

E-mail addresses: jlmiralles@unex.es*,marmiralles@unex.es, ines.lisboa@ipleiria.pt
} 


\section{Introduction}

In the actual context of uncertainty, instability and financial crisis, understanding firm's risk is a central theme not only for financial researchers but also for all individuals. The bankruptcy of the American bank Lehman Brothers, in 2008, questioned financial market confidence and caused bankruptcies, unemployment and excessive debt all over the world. The solvability of different banks was also questioned. More recently, the insecurity of the Greek financial system as well as the Portuguese one, due to the excess deficit, has led to an increase in financial distrust.

The firm total risk is the risk inherent in the firm's activity. It can result from internal or external factors and it can have impact in the firm return. The firm risk is a combination of systematic and unsystematic risk. The first type of risk, also called market risk, is the uncertainty common to all the firms in a market. The other type of risk is a firm specific and unique risk that affects firms from the same industry or with similar characteristics (Ross et al., 2011).

Increased risk has an impact on those directly and indirectly related with the firm. Therefore, it is important to comprehend which factors affect it (Wright et al., 1996). Several studies have been carried out so as to measure the impact of ownership structure on risk (Gadhoum and Ayadi, 2003, Díez et al., 2008, John et al., 2008). However, these studies are often focused on the bank sector, and headquartered in the U.S., and major European countries, neglecting other industries and regions.

This study attempts to fill previous gaps in empirical literature with regard to corporate finance. We not only analyze the risk differences between family and non-family firms, as also analyze in more detail the family impact on it using two alternative measures of the family influence: family ownership and F-PEC scale, an alternative measure of family impact. We analyze all quoted firms (from all industries) of one small developed country: Portugal, which had some solvency problems. We attempt to explain why the majority of firms all over the world are family firms.

The behavioral agency theory suggests that family presence in the firm may lead to risk reduction due to the long-term perspective and aim to pass on the firm (Gomez-Mejia et al., 2007, Bretton-Miller et al., 2011). The family may suffer from the risk concentration in a unique asset, the firm, and though they may be risk averse to business opportunities since it may put in place their personal wealth, reputation and recognition (Patel and Chrisman, 2013). Although, the impact may depends on the levels of family control and on the existence of growth opportunities. Following the agency theory of Jensen and Meckling (1976), ownership concentration may lead to expropriations of the firm's wealth. As to family firms the family socioemotional wealth is enhanced, the expropriation of the minority investors wealth may occur only when the firm as growth opportunities.

Based on theoretical arguments and the behavioral agency theory, we developed the models to prove the validity of our hypotheses. Our results show that family influence and control do not impact the firm risk. Only the firm size, return and growth opportunities influence the firm risk.

This result is of greater importance in the sense that, as previous studies found that family and nonfamily firms present different return, it suggests that financial investors may have advantages to invest in family firms since the return may be higher and the firm risk taking is similar. Likewise our study is valuable to all individuals, financial investors or no, to deeply understand the firm risk and to know how to deal with it.

The remainder of the article is organized as follows. Section 2 briefly reviews prior literature on this issue and outlines the hypotheses of this study. Section 3 describes the sample structure, dataset and methodology. Section 4 contains our empirical results and the discussion. Finally, section 5 highlights the main conclusions.

\section{Theoretical background}

\subsection{Family firm definition}

One of the major problems of family firm studies is the definition of a family business (Astrachan et al., 2002). There is no general accepted concept of family firms; each researcher uses his own one (Chami, 2001).

There are three main ways to define a family business. Some researcher are more concerned with ownership, others focus on the family ownership and management involving, while others are worry with generational transfer (Astrachan et al., 2002). Klein (2000) states that a family can influence a business through ownership, corporate governance, and/or management. 
To Anderson and Reeb (2003) a firm is classified as a family firm when the founding family has an equity stake in the firm and/or there are family members present on the board of directors. To Fahlenbrach (2009), a family firm is one where the $\mathrm{CEO}$ is the founder or co-founder of the firm. Gomez-Mejia et al. (2007) argue that a firm is a family firm when it is owned and operated by the founding family. Miller et al. (2007) define a family firm as one in which multiple members of the same family are involved as major owners or managers.

We focus our definition on "family controlled". To our concern a family firm is a company that is owned and controlled by a family. This definition is similar to that of Anderson and Reeb (2003), and Miralles-Marcelo et al. (2013). In Portugal the tradition is relevant, so if a firm was created by a family or an individual with the major control, if that family remained a major investor when the firm went public, and if the family is present on the board of directors as CEO or holds another position which may control the CEO's decisions, the family's identity and culture is present in the firm.

We did not establish a minimum threshold for family involvement in ownership as some researchers have done for several reasons. First, Martín-Reyna and Duran-Encalada (2012) argue that the cultural and legal contexts influence the family business. Second, for the majority of family firms in our sample, the families hold more than $10 \%$ of the company shares (the minimum threshold defined by some researchers such as Gomez-Mejia et al. 2003). Third, we assure that the family self-interests are accomplish since the family is present on the board of directors. Finally, for all the family firms in our sample we have carried out a double check to confirm our classification of family firms. We looked at the firm's history to understand if family involvement in the process decision was guaranteed.

Moreover, we do not use the F-PEC scale to classify the firm into family or non-family firm or into different clusters of family firms: weak, normal and strong as some researcher have done (Jaskiewicz et al., 2005). We have used it as an alternative solution to measure the family impact in the firm. This scale comprises three subscales: power, experience and culture, being more accurate to measure the family influence in the firm.

\subsection{Research focus and hypothesis}

Various studies find that family firms present at least similar financial performance than that of non- family firms (Anderson and Reeb, 2003, Barontini and Caprio, 2006, Martin-Reyna and DuranEncalada, 2012, among others). Moreover, some researchers show that family firms outperform nonfamily ones in regard to stock market performance (Corstjens et al., 2006, Fahlenbrach, 2009, MirallesMarcelo et al., 2013).

These facts suggest risk differences between family and non-family firms, due to the binomial risk-return tradeoff. If family firms present higher return, their exposition to risk may be also different. Some researchers found that family firms present higher risk than their non-family counterparts due to the lack of family wealth diversification (Sullivan and Spong, 1988, Bartholomeusz and Tanewski, 2006).

Although, for another side, family firms may present less risk that non-family firms. The family wealth and their personal risk directly depend on the firm. The family may suffer from the risk concentration in a unique asset, the firm (Erbetta et al., 2013). Indeed the family may tries to improve risk management and, in turn, reduce it. The behavioral theory argues that family owners pursue not only financial interests but also non-economic goals that create socio-emotional wealth (GomezMejia et al., 2007). The family has affective needs, such as identity, reputation, the need for control and the perpetuation of the family dynasty, which can bring unique and value-added skills to the firm and impact on its risk (Gomez-Mejia et al., 2003). This suggests that the family only makes risky investments when it is important to sustain the firm in the future. The family is risk averse whenever their socioemotional wealth is threatened (Patel and Chrisman, 2013).

As a result, the following hypothesis naturally follows:

Hypothesis 1: Family firms present less risk than non-family firms.

Despite the differences in risk between family and non-family firms, as family firms are not a homogeneous group, the firm risk may depend on the family control (Mazzi, 2011).

When the family control is higher, the family may tries to reduce the firm risk. External capital is avoided since augment the firm financial risk and may jeopardize the family control (Patel and Chrisman, 2013). Moreover, new and innovative investments or activities and useful strategic initiatives which could improve the firm value may 
be avoided if these may threaten the family wealth

Portugal are family controlled. Around $70 \%$ of

Table 1. Sample Structure

\begin{tabular}{llll}
\hline & Number of Firms & $\%$ & Number of observations \\
\hline Family Firms & 37 & $47,4 \%$ & 383 \\
Non-Family Firms & 41 & $52,6 \%$ & 367 \\
\hline This table presents the average number of firms and percentage and total number of observations (from 1999 to 2012) of family and nonfamily \\
firms included in our sample. Family firms are firms owned and controlled by a family.
\end{tabular}

and reputation (Bretton-Miller et al., 2011).

Taken together, these arguments suggest the following hypothesis:

Hypothesis 2: Higher family control reduces the firm risk.

Díez et al. (2008) prove that family impact in the firm risk is related with the firm's growth opportunities. Increasing risk is not economically rational when the firm lacks growth opportunities as in this case the probability of the firm's failure is higher (Gomez-Mejia et al., 2003). When the firm has free cash flows and new and innovative projects to invest in, the family may try to satisfy its selfinterests, leading to risky decisions (Wright et al., 1996).

This lead to the following hypothesis:

Hypothesis 3: Firms with growth opportunities present higher risk than those with reduced ones.

\section{Data and methodology}

\subsection{Sample selection}

Our sample includes listed firms of Euronext Lisbon, during the period of 1999 , the date of the introduction of the euro, until 2012. We study the Portuguese firms for several reasons. First, Portugal is a small-sized financial market with a growing importance in the world financial market. In regards to risks, Portugal is a country in vogue not only because some banks had some solvency problems (for example, Banco Português de Negócios) but also some policies of contraction were applied to reduce the economic deficit.

Second, the most dominant companies in
Portuguese firms and half of the Portuguese listed firms are family firms. Third, the majority of studies relating family issues and risk are focused on the bank sector, and headquartered in the U.S., and major European countries, neglecting other industries and regions. We analyze a small financial market and all industries, which is a form of interesting research intended for expanding international evidence, comparing it with existing results for major countries and extrapolating it to countries with similar characteristics.

\subsection{Data sources}

We use diverse databases to avoid misunderstandings and lack of information, and to build a cohesive sample. Our first concern was classifying firms into family ones. In this context, information on ownership was collected from Amadeus and Reuters databases. For each year in analysis, we analyze the names and ownership percentage of family owners. We also analyze the names of the members of the board of directors and the supervisory board.

Then we manually classify firms into family and non-family. A firm is classified as a family firm whenever there is fractional equity ownership of the founding family and the presence of family members on the board of directors. All the others are nonfamily firms. 1 presents the sample structure.

Observing Table 1 we find that the number of non-family firms is higher than the number of family firms but the difference is not significant and the total number of observations is higher to family firms, suggesting that the presence of family firms in the market is older.

To introduce the firm's identity and analyze

Table 2. Family Control

\begin{tabular}{lll}
\hline & \%Fam & Fam (F-PEC) \\
\hline Mean & $36.52 \%$ & $71.55 \%$ \\
Std. Dev. & 0.247 & 0.294 \\
\hline
\end{tabular}

This table presents the mean value and standard deviation (from 1999 to 2012) of family ownership measure by the percentage of ownership detained by the family (\%Fam) and the F-PEC scale (Fam (F-PEC)). 
whether it has an impact on the firm's risk we use a dummy variable which is one when the firm is a family firm and zero otherwise (Dfam). The family ownership (\%Fam) is the percentage of ownership detain by the family. The F-PEC scale was calculated using the formula introduced by Klein (2000):

Where EQ is the equity ownership, BoD is the board of directors, SB is the supervisory board. The first addend measures the family ownership, the second addend is the proportion of family members in the board of directors over the total member, and the third addend is the proportion of family members in the supervisory board over the total number. In Table 2 we present the mean values and standard deviation of $\%$ Fam and Fam (F-PEC).

Family control is significantly higher using the FPEC scale than the family ownership. This fact suggests that the presence of family members on the board of directors is high. It is important to point out that the presence of family members in the supervisory board is almost inexistent since the Portuguese legal law forces the independence of this board.

Analyzing the mean values we can argue that the majority of the Portuguese family firms are classified according to Jaskiewicz et al. (2005) as a weak family owned business. In our definition we did not established a minimum threshold for family ownership and control, as some researchers did since we focus on "family controlled" (Gomez-Mejia et al., 2011). Likewise to our aims we think that the family presence, culture and identity in the firm are guarantee.

Then we collected financial information from the Thomson DataStream database. The firm risk is the firm's volatility. We first compute the firm's return using its daily stock prices and then we calculate the standard deviation of 12 monthly returns. We also introduce some control variables to deal with firm's characteristics. The MTBV is the firm market-tobook value; the firm size (size) is the natural logarithm of the firm's assets; the debt is the ratio of total debt over assets, the ROA is the firm's return on asset; capex is the ratio of the capital expenditures over sales; the sales growth is the annual growth of the total sales; DGO is a dummy variable which captures the firm's growth opportunities and is equal to one when the firm has growth opportunities (market-to-book value higher than 1) and zero otherwise. We also control for industry using the 2 digit SIC-code.

\subsection{Methodology}

To validate our hypotheses we use panel data methodology, which is the methodology most commonly used in corporate governance studies. We also control for unexpected heterogeneity, which is usual in governance issues due to firms' specificities, and for biased results (Pindado et al., 2008). This methodology also solves the potential endogeneity problem between ownership structure and firm performance and risk.

The models were estimated using the GMM (Generalized Method of Moments) approach of Mackinlay and Richardson (1991), which is a more accurate estimation method to avoid biased results. Following Pindado et al. (2008) we use as instrumental variables the ones at the right hand side of the equations.

We run the following regression to measure the impact of family business on the firm risk:

Risk $=\alpha_{t}+\beta_{1} \times D$ fam $_{t}+\beta_{2} \times M T B V_{t}+\beta_{3} \times$ Size $_{t}+\beta_{4} \times$ Debt $_{t}+\beta_{5} \times R O A_{t}+\beta_{6} \times$ Capex $_{t}+\beta_{7} \times S . G_{\cdot t}$

We use the regression of firm risk measure against the dummy variable, which is one when the firm is a family firm and zero otherwise, to validate hypothesis 1. We also include some control variables.

This model is similar to that of Jo and Ha (2012). They analyze the corporate social responsibility impact on the firm risk instead of family impact, but the aim of both studies are similar which make it relevant to use a similar model.

To better understand the family firms, which are our main aim, we define the following model:

Risk $=\alpha_{t}+\beta_{1} \times \%$ fam $_{t}+\beta_{2} \times M T B V_{t}+\beta_{3} \times$ Size $_{t}+\beta_{4} \times$ Debt $_{t}+\beta_{5} \times R O A_{t}+\beta_{6} \times$ CapExp $_{t}+\beta_{7} \times$ Sales Growth

This second model allows us to understand if the family ownership impacts the firm risk. We then substitute the \%Fam by the Fam (F-PEC) to confirm the robustness of our conclusion and to analyze if the F-PEC scale, which contains three subscales: power, experience and culture, is more accurate to analyze the family impact on firm risk.

We also make an additional estimation to each model in which we introduce a dummy variable to measure the firm growth opportunities in order to see if it has an impact on the firm risk as Díez et al. (2008) argue. 
Table 3. Summary Statistics

\begin{tabular}{llllllll}
\hline \multicolumn{7}{c}{ Panel A: Descriptive Statistics } \\
\hline Mean & Risk & MTBV & Size & Debt & ROA & Capex & S.G. \\
Median & 0.031 & 1.709 & 5.583 & 0.298 & 0.013 & 0.102 & 0.185 \\
Maximum & 0.022 & 1.150 & 5.536 & 0.299 & 0.017 & 0.035 & 0.050 \\
Minimum & 0.352 & 34.340 & 7.997 & 17.120 & 0.679 & 6.079 & 24.379 \\
Std. Dev. & 0.000 & -96.120 & 2.431 & -0.585 & -1.182 & 0.000 & -1.000 \\
Skewness & 0.035 & 4.702 & 1.028 & 0.650 & 0.099 & 0.309 & 1.189 \\
Kurtosis & 4.137 & -10.5890 & 0.094 & 23.151 & -3.106 & 12.194 & 15.870 \\
& 27.101 & 259.533 & 2.898 & 600.328 & 44.593 & 206.450 & 292.246 \\
\hline Risk & & & Panel B: Correlation coefficients & & \\
MTBV & -0.090 & 1 & Size & Debt & ROA & Capex & S.G. \\
Size & -0.316 & 0.087 & 1 & & & & \\
Debt & -0.025 & -0.012 & 0.067 & 1 & & & \\
ROA & -0.170 & 0.015 & 0.094 & -0.076 & 1 & & \\
Capex & -0.032 & 0.016 & 0.151 & 0.011 & 0.056 & & \\
S.G. & 0.017 & 0.006 & -0.080 & -0.034 & 0.034 & 0.027 & 1 \\
\hline
\end{tabular}

Panel A presents descriptive statistics, namely mean, maximum, minimum, standard deviation, skewness and kurtosis, for the variables include in our models: risk is the standard deviation of twelve months return, MTBV is the firm market-to-book value, size is the natural logarithm of the firm's assets, debt is the ratio of total debt over assets, ROA is the firm's return on asset, capex is ratio of the capital expenditures over sales, sales growth (S.G.) is the annual growth of the total sales. Panel B reflects the correlation matrix for all these risk factors.

\section{Results and discussion}

The descriptive statistics (panel A) of our sample as well as the correlation matrix (panel B) are presented in Table 3. The following facts emerge, panel A: the firm risk mean is 0.031 and it is very volatile suggesting that the firms present different risk-taking. On average the market-to-book value is higher than one suggesting that there are diverse companies with growth opportunities. In our sample we have smaller and big firms. The mean value of size is 5.583. Finally, debt intensity, ROA, capex and sales growth ration are positive but also very volatile in the sample. Observing panel B we find that none of variables in our sample are highly correlated, at least not to a significant extent.

Before presenting the results from the multivariate analysis, we compare the mean values of the variables of our sample to family and nonfamily firms and analyze if there are significant differences between them. Results are present in Table 4.
As we observe in Table 4, family and non-family firms present, on average, similar risk, market-tobook value, size, debt intensity and sales growth. Moreover, family firms present higher return (ROA) and less capital expenditures than non-family ones. This univariate analysis suggests that there is no impact of family control on the firm risk. To corroborate this result we estimate the first model proposed. Results are present in Table 5.

As we see in table 5 , the family presence in the firm does not impact its risk, contrary to our expectations in hypothesis 1. Miralles-Marcelo et al. (2013) found that family firms outperform nonfamily ones. Although, even if family firms present different return compared to non-family firms, their risk is similar. Likewise we do not find the binomial relation risk-return.

When we include the growth opportunities variable we find that firms with growth opportunities present less risk than the others, which is the opposite of our hypothesis 3 and of the results found

Table 4. Variables difference of a Mean Test

\begin{tabular}{llllllll}
\hline & Risk & MTBV & Size & Debt & ROA & Capex & S.G. \\
\hline Family & 0.030 & 1,607 & 5.576 & 0.291 & $0.021 * * *$ & $0.083 * *$ & 0.222 \\
Non-Family & 0.032 & 1,814 & 5.591 & 0.306 & 0.004 & 0.122 & 0.146 \\
\hline
\end{tabular}

This table presents the mean values of risk (the standard deviation of twelve months return), MTBV (the firm market-to-book value), size (the natural logarithm of the firm's assets), debt (the ratio of total debt over assets), ROA (the firm's return on asset), capex (the ratio of the capital expenditures over sales), sales growth (S.G. - the annual growth of the total sales) of family and nonfamily firms. The sample period is 1999-2012. Family firms are firms owned and controlled by a family. 
Table 5. Family impact on firm risk

\begin{tabular}{|c|c|c|}
\hline & Risk (1) & Risk (2) \\
\hline $\mathrm{C}$ & $0.090 * * *$ & $0.086 * * *$ \\
\hline$D_{\text {fam }}$ & -0.001 & -0.002 \\
\hline MTBV & $-0.001 *$ & -0.000 \\
\hline Size & $-0.010 * * *$ & $-0.008 * * *$ \\
\hline Debt & -0.001 & -0.001 \\
\hline ROA & $-0.050 * * *$ & $-0.044 * * *$ \\
\hline Capex & 0.002 & 0.002 \\
\hline S.G. & -0.000 & -0.000 \\
\hline $\mathrm{D}_{\mathrm{GO}}$ & - & $-0.015 * * *$ \\
\hline $\mathrm{R}^{2}$ & $12.44 \%$ & $16.03 \%$ \\
\hline Adj. $R^{2}$ & $11.62 \%$ & $15.12 \%$ \\
\hline J-Statistic & 0.000 & 0.000 \\
\hline \multicolumn{3}{|c|}{$\begin{array}{l}\text { This table presents the estimates of first model proposed. The firm risk, measured as the firm's return volatility, is regressed against } D_{\text {Fam }} \\
\text { (dummy variable which equals to one when the firm is a family firm and zero otherwise), MTBV (the firm market-to-book value), size (the } \\
\text { natural logarithm of the firm's assets), debt (the ratio of total debt over assets), ROA (the firm's return on asset), capex (the ratio of the capital } \\
\text { expenditures over sales), and sales growth (S.G.- the annual growth of the total sales). The differences between the first model (risk } 1 \text { ) and the } \\
\text { second one (risk } 2 \text { ) is that in the second one we introduce a dummy variable which equals to one when the firm as growth opportunities and } \\
\text { zero otherwise. The last three rows show the statistics R-squared, Adjusted R-squared, and J-statistic. } \\
*, * *, * * \text { Significant at the } 10 \%, 5 \% \text { and } 1 \% \text { levels, respectively. }\end{array}$} \\
\hline
\end{tabular}

Table 6. Family control impact on the firm risk

\begin{tabular}{|c|c|c|c|c|}
\hline & Risk (1A) & Risk (2A) & Risk (1B) & Risk (2B) \\
\hline $\mathrm{C}$ & $0.102 * * *$ & $0.100 * * *$ & $0.107 * * *$ & $0.106 * *$ \\
\hline$\%$ Fam & 0.000 & -0.000 & - & - \\
\hline Fam (F-PEC) & - & - & -0.006 & -0.007 \\
\hline MTBV & $-0.002 * * *$ & -0.001 & $-0.002 * * *$ & -0.001 \\
\hline Size & $-0.013 * * *$ & $-0.012 * * *$ & $-0.014 * * *$ & $-0.013 * * *$ \\
\hline Debt & $0.023 * *$ & $0.026 * * *$ & $0.022 * *$ & $0.025 * * *$ \\
\hline ROA & $-0.082 * * *$ & $-0.068 * * *$ & $-0.084 * * *$ & $-0.068 * * *$ \\
\hline Capex & $0.021 *$ & $0.021 * *$ & $0.021 *$ & $0.021 * *$ \\
\hline S.G. & 0.001 & 0.001 & 0.001 & 0.001 \\
\hline $\mathrm{D}_{\mathrm{GO}}$ & - & $-0.013 * * *$ & - & $-0.013 * * *$ \\
\hline $\mathrm{R}^{2}$ & $19.06 \%$ & $21.36 \%$ & $19.28 \%$ & $21.70 \%$ \\
\hline Adj. $R^{2}$ & $17.55 \%$ & $19.68 \%$ & $17.77 \%$ & $20.02 \%$ \\
\hline J-Statistic & 0.000 & 0.000 & 0.000 & 0.000 \\
\hline
\end{tabular}

This table presents the estimates of first model proposed. The firm risk, measured as the firm's return volatility, is regressed against \%Fam (model A) (Fam-PEC - model B), family ownership (family control calculated using the F-PEC scale), MTBV (the firm market-to-book value), size (the natural logarithm of the firm's assets), debt (the ratio of total debt over assets), ROA (the firm's return on asset), capex (the ratio of the capital expenditures over sales), and sales growth (S.G.- the annual growth of the total sales). The differences between the first model (risk 1) and the second one (risk 2) is that in the second one we introduce a dummy variable which equals to one when the firm as growth opportunities and zero otherwise. The last three rows show the statistics R-squared, Adjusted R-squared, and J-statistic.

$*, * *, * * *$ Significant at the $10 \%, 5 \%$ and $1 \%$ levels, respectively.

by Díez et al. (2008). To Portugal, the firms without growth opportunities present higher risk may be because they invest in innovative projects in order to try to subsist in the competitive market, especially in a financial crisis period.

We also find that large-size firms and firms with higher return on assets present less risk. It is important to point out that firms with higher growth opportunities are normally big-size firms with more return, less problems of failure and which can gain from scales economies and long-term experience. Finally we can see that the constant in the model is significant to a level of $1 \%$, which suggest that there are other variables that can explain the firm risk.

Family firms, as well as all the groups of firms, are not a homogeneous group. To analyze if the family control in the family firms firm influences its risk we estimate the second model. Results are presented in Table 6.

Neither the percentage of family ownership, (models A) neither the family influence measured by the F-PEC scale (models B) causes an impact on the firm risk. Therefore, our second hypothesis is not validated. To Portugal, the firm risk differences are not explained by the family control and influence in the firm but only by the firm size, return and growth opportunities.

The impact of the control variables in the firm risk is the same as explained in the previous model. To family firms, the debt intensity is also important to explain the firm risk. Higher levels of debt cause an increase in the firm risk due to financial distress. 
As well as we state before, there are other variables not included in the model which could explain the firm risk.

\section{Conclusion}

Family firms are present all over the world. These firms not only are concerned with the firm value maximization but also with the family socioemotional wealth. Therefore, they have unique characteristics compared to non-family firms which can enhance its return and in turn may have impact on the firm risk.

Our study focuses on the analysis of the risk differences between family and non-family firms. We also search for the impact of the family control on the firm risk, to better understand the family firms' presence in all the economies. Previous researchers, as Mazzi (2011) found that there are diverse sources of family firm heterogeneities as the percentage of family ownership and control. We use two ways to measure the family control: the family ownership, the most common measure used, and the F-PEC scale, an alternative measure introduced by Astrachan et al. (2002). This measure solves the definition problems of family firms since it includes three subscales: power, experience and culture, assuring that the family identity in the firm.

In this context, we analyze all Portuguese publicly traded corporations, during the period of 1999 and 2012. This country is almost unexplored in corporate governance issues, but it has the predominance of family firms. Around one-half of PSI-20 and of all listed firms are family firms, which brings relevance to this study.

Our overall results show that the family influence and control has no impact on the firm risk. Only the firm size, return and growth opportunities influence it. Even though the return of family and non-family firms is distinct, their risk is similar. This conclusion suggest that or the systematic and unsystematic risk of family and non-family firms is different and the combination of the two compensate that differences, or financial investors may have benefits to invest in family firms since they may present higher levels of return and the same risk.

Moreover, contrary to previous results, to Portugal if the firm has growth opportunities, the firm risk decreases may be because the firm has opportunity to do something new and innovative which can be the solution to survive in the competitive market. These results may be influenced by the financial crisis period which has begun in 2008 and last till now to Portugal.

Our findings are especially relevant for theoretical and practical reasons. First, we contribute to extending the literature. We analyze the firm risk, a major concern especially in periods of recession. Second, our aim is to deeply understand whether the firm risk depend on family control. Likewise we use some alternative measures of the family control to corroborate our results.

Third, our results are valuable to stakeholders in general. Shareholders and directors can understand which factors influence the firm risk. Financial investors may recognize the benefits and limitations of investing in Portuguese family firms. MirallesMarcelo et al. (2013) found that the Portuguese family firms present an abnormal return than nonfamily firms, but these firms do not present different risk. Likewise, investing in family firms may represent a higher return and the same risk taking. Finally, firms' consultants can support their knowledge about the survival and prosperity of family firms.

\section{Bibliografía}

Anderson, R., and Reeb, D., (2003). Founding-Family Ownership and Firm Performance: Evidence from the S\&P500. Journal of Finance, 58 (3), 1301-1328.

Astrachan, J., Klein, S., and Smyrnios, K., (2002). The F-PEC Scale of Family Influence: A Proposal for Solving the Family Business Definition Problem. Family Business Review, 15 (1), 45-58.

Barontini, R., and Caprio, L., (2006). The Effect of Family Control on Firm Value and Performance: Evidence from Continental Europe. European Financial Management, 12, 689-723.

Bartholomeusz, S., and Tanewski, G., (2006). The Relationship between Family Firms and Corporate Governance. Journal of Small Business Management, 44 (2), 245-267.

Berle, A., and Means, G., (1932). The Modern Corporation and Private Property. Hancourt, Brace \& World, Inc. Copyright, New York (Republished 1968).

Breton-Miller, I., Miller, D., and Lester, R., (2011). Stewardship or Agency? A Social Embeddedness Reconciliation of Conduct and Performance in Public Family Businesses. Organization Science, 22 (3), 704721.

Chami, R., (2001). What's Different about Family Business? Working Paper International Monetary Fund, $\mathrm{WP} / 01 / 70$. 
Corstjens, M., Maxwell, K., Peyer, U., and Van der Heyden, L., (2006). Stock Market Performance of Family Firms. IFERA 2006 Research Conference (Finland).

Díez, J., García, C., and López-de-Foronda, O., (2008). La Influencia de los Grandes Accionistas en el Riesgo Corporativo: Un estudio para Empresas Europeas no Financieras. XVIII Congreso Nacional ACEDE, Léon (Spain).

Erbetta, F., Menozzi, A., Corbetta, G., and Fraquelli, G., (2013). Assessing Family Firm Performance using Frontier Analysis Techniques: Evidence from Italian Manufacturing Industries. Journal of Family Business Strategy, 4 (2), 106-117.

Fahlenbrach, R., (2009). Founder-CEOs, Investment Decisions, and Stock Market Performance. Journal of Financial and Quantitative Analysis, 44, 439-466.

Gadhoum, Y., and Ayadi, M., (2003). Ownership Structure and Risk: Canadian Empirical Analysis. Quarterly Journal of Finance and Accounting, 42, 19-39.

Gomez-Mejia, L., Cruz, C., Berrone, P., and De Castro, J., (2011). The Bind that Ties: Socioemotional Wealth Preservation in Family Firms. The Academy of Management Annual, 5 (1), 653-707.

Gomez-Mejia, L., Haynes, K., Nuñez-Nickel, M., Jacobson, K., and Moyano-Fuentes, J., (2007). Socioemotional Wealth and Business Risks in Familycontrolled Firms: Evidence from Spanish Olive Oil Mills. Administrative Science Quarterly, 52, 106-137.

Gomez-Mejia, L., Larraza-Kintana, M., and Makri, M., (2003). The Determinants of Executive Compensation in Family-Controlled Public Corporations. Academy of Management Journal, 46 (2), 226-237.

Jaskiewicz, P., González, V., Menéndez, S., and Schiereck, D., (2005). Long-run IPO Performance Analysis of German and Spanish Family-Owned Business. Family Business Review, 18 (3), 179-202.

Jensen, M., and Meckling, W., (1976). Theory of the Firm: Managerial Behaviour, Agency Cost and Ownership Structure. Journal of Financial Economics, 3 (4), 305-360.

Jo, H., and Na, H., (2012). Does CSR Reduce Firm Risk? Evidence from Controversial Industry Sectors. Journal of Business Ethics, 110, 441-456.

John, K., Litov, L., and Yeung, B., (2008). Corporate Governance and Risk Taking. Journal of Finance, 63 (4), 1679-1728.

Klein, S. (2000). Family Business in Germany: Significance and Structure. Family Business Review, 13 (3), 157-181.

La Porta, R., Lopez-de-Silanes, F., and Shleifer, A., (1999). Corporate Ownership around the World. Journal of Finance, 54, 471-517.
Mackinlay, A., and Richardson, M., (1991). Using Generalized Method of Moments to Test Mean-Variance Efficiency. Journal of Finance, 46, (2), 511-527.

Martín-Reyna, J., and Durán-Encalada, J., (2012). The Relationship among Family Business, Corporate Governance and Firm Performance: Evidence from the Mexican Stock Exchange. Journal of Family Business Strategy, 3, 106-117.

Mazzi, C. (2011). Family Business and Financial Performance: Current State of Knowledge and Future Research Challenges. Journal of Family Business Strategy, 2 (3), 166-181.

Miller, D., Breton-Miller, I., Lester, R., and Cannella Jr., A., (2007). Are Family Firms Really Superior Performers? Journal of Corporate Finance, 13, (5), 829858.

Miralles-Marcelo, J.L., Miralles-Quirós, M.M., and Lisboa, I., (2013). Stock Performance of Family Firms in the Portuguese Market. Applied Financial Economics, 23 (22), 1721-1732.

Patel, R., and Chrisman, J., (2013). Risk Abatement as a Strategy for R\&D Investments in Family Firms. Strategic Management Journal, DOI: 10.1002/smj.2119.

Pindado, J., Requejo, I., and De La Torre, C., (2008). Does Family Ownership Impact Positively on Firm Value? Empirical Evidence from Western Europe. XVI Foro de Finanzas (Barcelona, Spain).

Ross, S., Westerfield, R., and Jordan, B., (2011). Essentials of Corporate Finance. McGraw-Hill (Boston), 7 th edition.

Sullivan, R., and Spong, K., (1988). How does Ownership Structure and Manager Influence Risk? A Look at Ownership Structure, Manager Wealth, and Risk in Commercial Banks. Financial Industry Perspectives: Federal Reserve Bank of Kansas City, 15-44.

Wright, P., Ferris, S., Sarin, A., and Awasthi, V., (1996). Impact of Corporate Insiders, Blockholder, and Institutional Equity Ownership on Firm Risk Taking. Academy of Management Journal, 39 (2), 441-46 